\title{
Faculty Participation in Asynchronous Learning Networks: A Case Study of Motivating and Inhibiting Factors
}

\author{
Catherine C. Schifter \\ 667 Ritter Annex (004-00) \\ College of Education \\ Temple University \\ Philadelphia, PA 19122 \\ Phone: 215-204-3477 \\ Fax: 215-204-2666 \\ E-mail: schifter@nimbus.temple.edu
}

\begin{abstract}
This case presents and compares the top five motivating and inhibiting factors for faculty participation in Asynchronous Learning Networks (ANL) or distance education (DE) as reported by faculty participators and non-participators, and administrators. While faculty and administrators agreed strongly on what inhibits faculty from participating in ALN/DE programs, there were significantly different perceptions on what motivates faculty to participate across the three groups. For ALN/DE programs to succeed, faculty participation is imperative; therefore, program administrators need to understand why faculty participate.
\end{abstract}

\section{KEYWORDS}

Asynchronous Learning Networks (ALN), Distance Education (DE), Faculty Motivators, Faculty Inhibitors

\section{INTRODUCTION}

Distance education (DE) is not new to higher education. Correspondence programs have served higher education students for over a hundred years. What makes DE different and intriguing today to universities, colleges, and many others, is the use of interactive computer-mediated communication (CMC) systems to create Asynchronous Learning Networks (ALN) and learning 5 communities.

The literature on ALN/DE has much information describing the students as older, mature, selfinitiators interested in outcomes [1], [2], [3], [4]; taking time away from family and careers to go back to school [5], [6]; less likely to be female [7], [8], [9]; and less likely to be from a minority population [10], [11], [12]. There are articles on "how-to-do" DE [13], [14], [15], [16], addressing such issues as distance learning environments, design issues, and case studies of successful ALN/DE courses. What is missing from the ALN/DE literature is a significant discussion of the faculty, full or part time, who teach the courses and why they participate while others do not.

Taylor and White reported faculty preferred conventional face-to-face (FTF) courses over distance teaching due to the degree of interpersonal contact available in each mode [17]. Fewer 
interactions with distant students led to less faculty interest to participate, but it should be noted that this study was done at a time when computer-mediated communication (CMC) was limited in scope. Clark showed through a national survey that faculty support for distance courses was tempered by concern for quality of interaction, administrative support, and rewards [18]. And Olcott and Wright suggested that faculty are not enthusiastic about participating in DE due to a lack of administrative support [19].

In some institutions of higher education, how to entice faculty participation in ALN/DE has been thought of in terms of financial rewards and incentives. Wolcott [20] discussed how teaching in $\mathrm{DE}$ is not highly valued and is not related to tenure and promotion decisions. Dillon studied faculty rewards in telecourses and discovered faculty participated "for a variety of personal reasons, ranging from diversity of experience to altruism toward the non-traditional learner" [ 21 (p. 42)]. Dillon and Walsh reviewed 225 articles and concluded that "...faculty motivation to teach at a distance results from intrinsic [prestige, self esteem] rather than extrinsic incentives [monetary rewards]" [르 (p. 16)].

Knowing what motivates and inhibits faculty will facilitate implementation of new and expansion of current ALN/DE programs. For instance, the faculty role in ALN/DE changes from a teacher centered model to one more student-centered [23], [24], [25]. These changes are difficult for some faculty who know and are comfortable only with the traditional form of classroom-based teaching. In addition, teaching skills for successful teaching at a distance are different from those required to teach FTF [26], [27]; however, faculty training programs tend to be limited to how to use the computers or software, not on how to teach at a distance [28]. These two factors may mean that the faculty who participate in ALN/DE are interested in trying new ways to reach students, and likely to be comfortable using computers, but this is just speculation. The movement toward establishing Virtual Campuses/Universities/Schools is disturbing for many faculty and the national teachers unions. Administrators need to understand their faculty population if they are to provide an environment that maximizes motivating factors and minimizes inhibiting factors for faculty participation in ALN/DE, and not merely resort to financial incentives.

Faculty participation is imperative for ALN/DE programs to succeed. How do faculty from a Research I, state-related university perceive participation in ALN/DE? This exploratory study surveyed faculty use of computers in teaching and learning activities, including perceptions of motivating and inhibiting factors for participating in DE.

\section{METHODS}

With permission of Dr. Kristen Betts [29], a modified version of the survey she developed in 1998 was used [30]. Dr. Betts survey was developed for her dissertation research at George Washington University, in which she examined the relationships between 1) faculty participation and intrinsic motivation, 2) faculty participation and extrinsic motivation and 3) faculty participation and inhibiting factors. Her survey was developed using the current literature about faculty motivators and inhibitors as a guide, and has face validity. Unfortunately, since her survey had only been used once in her own study, there was no validity and reliability data as would be true with any new instrument. Her survey was appropriate for this study because it specifically addresses the issues of motivating and inhibiting factors for DE. The modifications made to the survey reflected only slight institutional differences. 
The survey was distributed in April 1999 to all full-time faculty and twenty-five senior administrators, including all deans at a large urban, Research I state related institution. After accounting for faculty on leave (paid or unpaid) from the university, the target faculty population totaled 1312 faculty. After two weeks, a gentle reminder was sent to all members of the target population, faculty and administrators, thanking those who had already completed and returned the survey and offering to send another survey in the event the first copy had been misplaced. Two hundred sixty-three completed and usable faculty surveys were returned for a response rate of $20 \%$. Eleven administrators returned the survey for a $44 \%$ response rate. The quantitative data was entered into a database and analyzed using SPSS, while the qualitative data was transcribed and analyzed using NUD*IST qualitative data analysis software. While the survey addressed many issues of faculty use of instructional technology in their teaching in the classroom and out, this paper will present only the top five factors that motivate and inhibit faculty participation in DE programs.

\section{RESULTS}

Faculty from every college in the institution was represented in the data. The largest percentage of total responses came from the College of Liberal Arts (16.7\%), followed by the schools of business and medicine ( $14.1 \%$ and $12.5 \%$, respectively).

One hundred and sixty-eight $(63.9 \%)$ of the faculty respondents were male, while $94(35.7 \%)$ were female. Twenty respondents (7.6\%) were under 30 years of age, 117 (44.5\%) were 30-45 years of age, $90(34.2 \%)$ were $45-60$ years of age, and $35(13.3 \%)$ were over 60 years old. One hundred and twenty-six (47.9\%) respondents were full professors, $74(28.1 \%)$ were associate professors, $47(17.9 \%)$ were assistant professors, and 16 (6.1\%) were instructors. Two hundred and sixty respondents were full time faculty. While the survey was sent to full-time faculty, two respondents indicated they were part-time faculty and one person did not answer this item. One hundred and eighty-six (70.7\%) were tenured, and $74(28.3 \%)$ indicated they were not. Of the 74 non-tenured faculty, $28(37.8 \%)$ were on tenure track, $36(48.6 \%)$ were not on tenure track, and $10(13.5 \%)$ did not indicate tenure track status. The sample resembled the demographic picture of the overall faculty of the institution as of the fall 1998. In addition, faculty were asked to selfidentify whether they participated in DE initiatives. Thirty-eight (14.4\%) faculty indicated they participated in DE. For the purpose of this study, this group is called "participators" and those who did not indicate participating in DE are called "non-participators."

A total of eleven administrators returned the self-study survey: six deans, two vice presidents, one vice provost, one associate dean, and one acting assistant dean. Of the eleven, only nine completed all sections of the survey, including those relating to motivating and inhibiting factors.

\section{A. Motivating Factors}

Faculty and administrators were asked to rate from 5 to $1(5=$ strongly agree; $1=$ strongly disagree) to what extent they believed 29 factors (see Table 1) had motivated or would motivate them to participate in DE. The results are presented based on mean scores in rank order high to low. The top five motivating factors for "participants" were personal motivation to use technology (M-1), opportunity to develop new ideas (M-12), opportunity to improve my teaching (M-28), opportunity to diversify program offerings (M-26) and greater flexibility for students (M25). The top five motivating factors for non-participating faculty were opportunity to develop new ideas (M-12), technical support provided by the institution (M-19), personal motivation to use technology (M-1), intellectual challenge (M-17) and overall job satisfaction (M-18). The top five motivating factors for faculty, according to administrators, were personal motivation to use 
technology (M-1), monetary support for participation (e.g., stipend, overload) (M-10), intellectual challenge (M-17), credit toward promotion and tenure (M-21) and release time (M-22).

\begin{tabular}{|rl|}
\hline No. & Factor \\
\hline 1 & Personal motivation to use technology \\
2 & Graduate training received \\
3 & Opportunity for scholarly pursuit \\
4 & Reduced teaching load \\
5 & Opportunity to use personal research as a teaching tool \\
6 & Requirement by department \\
7 & Support and encouragement from dean or chair \\
8 & Working conditions (e.g., hours, location) \\
9 & Job security \\
10 & Monetary support for participation (e.g., stipend, overload) \\
11 & Expectation by university that faculty participate \\
12 & Opportunity to develop new ideas \\
13 & Visibility for jobs at other institutions/organizations \\
14 & Professional prestige and status \\
15 & Grants for materials/expenses \\
16 & Support and encouragement from departmental colleagues \\
17 & Intellectual challenge \\
18 & Overall job satisfaction \\
19 & Technical support provided by the institution \\
20 & Career exploration \\
21 & Credit toward promotion and tenure \\
22 & Release time \\
23 & Distance education training provided by the institution \\
24 & Merit pay \\
25 & Greater course flexibility for students \\
26 & Opportunity to diversify program offerings \\
27 & Ability to reach new audiences that cannot attend classes on campus \\
28 & Opportunity to improve my teaching \\
29 & Support and encouragement from institutional administrators \\
\hline
\end{tabular}

Table 1. Motivating (M) Factor List.

A comparison was made of the top five motivating factors across the three groups. All three groups rated "personal motivation to use technology" highly, with participants and administrators agreeing this is the top motivating factor, and non-participants rating it third. The only other similarity between the two faculty groups was in rating "opportunity to develop new ideas" highly (participants $=2^{\text {nd }}$; non-participants $=1^{\text {st }}$ ). Also, administrators and non-participants agreed that "intellectual challenge" was a strong motivator (administrators $=3^{\text {rd }}$; non-participators $=4^{\text {th }}$ ). Otherwise, there were no similarities between the three groups.

An analysis of variance (ANOVA) of mean scores was calculated to test for significant differences between the three group ratings on the twenty-nine motivating factors. The results revealed highly significant differences between the groups on several motivating factors. Highly significant differences $(\mathrm{p}<.001)$ were found for monetary support for participation $(\mathrm{M}-10)$, where administrators rated this factor $2^{\text {nd }}$, participating faculty rated it $23^{\text {rd }}$ and non-participating faculty rated it $10^{\text {th }}$. Very significant differences $(\mathrm{p}<.01)$ were found for personal motivation to use technology (M1), reduced teaching load (M-4), credit toward promotion and tenure (M-21), 
release time (M-22), and DE training provided by the institution (M-23). Non-participants rated factor M-1 $3^{\text {rd }}$, while participants and administrators rated it $1^{\text {st }}$. Factor M-4 was rated extremely low by participators $\left(27^{\text {th }}\right)$, but less so by non-participators $\left(19^{\text {th }}\right)$ and administrators $\left(16^{\text {th }}\right)$. Both faculty groups rated factor M-21 much lower than administrators did, who rated it in the top five motivating factors. Participants and non-participants rated M-22 and M-23 lower than administrators, with administrators rating $\mathrm{M}-22$ in the top five motivating factors. Significant difference $(\mathrm{p}<.05)$ was found for opportunity to use personal research as a teaching tool $(\mathrm{M}-5)$, support and encouragement from department colleagues (M-16), technical support provided by the institution (M-19), career exploration (M-20), and merit pay (M-24). Non-participating faculty rated factors M-16 and M-20 lower than administrators and participating faculty, and participators rated M-5, M-19 and M-24 lower than non-participators and administrators.

\section{B. Inhibiting Factors}

The faculty and administrators were asked to rate from 5 to $1(5=$ strongly agree; $1=$ strongly disagree) to what extent they believed 17 factors (see Table 2) had inhibited or would inhibit them from participating in DE. The results are presented based on mean scores in rank order high to low. The top five inhibiting factors for participators in DE were lack of technical support provided by the institution (I-11), lack of release time (I-5), concern about faculty workload (I-1), lack of grants for materials/expenses (I-9), and concern about quality of courses (I-10). The top five inhibiting factors for non-participating faculty were lack of technical support provided by the institution (I-11), concern about quality of courses (I-10), concern about faculty workload (I-1), lack of distance learning training provided by institution (I-3) and lack of release time (I-5). The top five inhibiting factors for faculty, according to administrators, were lack of technical support provided by the institution (I-11), concern about faculty workload (I-1), lack of release time (I-5), lack of merit pay (I-12) and lack of grants for materials/expenses (I-9).

\begin{tabular}{|lll|}
\hline Factor & Factor \\
\hline 1 & Concern about faculty workload \\
2 & Negative comments made by colleagues about distance education teaching \\
& experiences \\
3 & Lack of distance education training provided by the institution \\
4 & Lack of support and encouragement from departmental colleagues \\
5 & Lack of release time \\
6 & Lack of professional prestige \\
7 & Lack of technical background \\
8 & Lack of support and encouragement from dean or chair \\
9 & Lack of grants for materials/expenses \\
10 & Concern about quality of courses \\
11 & Lack of technical support provided by the institution \\
12 & Lack of merit pay \\
13 & Lack of support and encouragement from institution administrators \\
14 & Lack of monetary support for participation (e.g., stipend, overload) \\
15 & Concern about quality of students \\
16 & Lack of salary increase \\
17 & Lack of credit toward promotion and tenure \\
\hline
\end{tabular}

Table 2. Inhibitor (I) Factor List. 
All three groups rated lack of technical support provided by the institution (I-11) as the top inhibiting factor for faculty participation in DE. A comparison of responses from the two faculty groups indicate similarities in three of the other top five inhibiting factors, even though the rank order was different. Administrators agreed with both faculty groups on concern about faculty workload (I-1) and lack of release time (I-5) as top inhibiting factors. They agreed with participating faculty that lack of grants (I-9) is a strong inhibiting factor; but rated lack of merit pay (I-12) as $4^{\text {th }}$ while participators rated this $15^{\text {th }}$ and non-participators rated it $12^{\text {th }}$. Where concern about quality of courses (I-10) was rated $5^{\text {th }}$ by participating faculty and $2^{\text {nd }}$ by nonparticipating faculty, administrators rated this factor $6^{\text {th }}$. Lastly, non-participating faculty rated lack of DE training (I-3) $4^{\text {th }}$, while participating faculty and administrators both rated this factor $9^{\text {th }}$.

An analysis of variance (ANOVA) of mean scores was calculated to test differences between the three group ratings of the seventeen inhibiting factors. The results revealed significant differences among the three groups on "lack of merit pay" (I-12) and "lack of credit toward promotion and tenure" $(\mathrm{I}-17)(\mathrm{p}<.05)$. The participating faculty rated factor $\mathrm{I}-1215^{\text {th }}$, non-participating faculty rated this factor $12^{\text {th }}$, and administrators rated it $4^{\text {th }}$. Participators rated factor I-17 $13^{\text {th }}$, nonparticipators rated it $16^{\text {th }}$, and administrators rated it $8^{\text {th }}$.

\section{DISCUSSION}

This study asked how faculty from a Research I, state-related university, perceive participation in $\mathrm{DE}$ in general. "Personal motivation to use technology" was clearly a strong motive for participating in ALN/DE at this institution, as noted by all parties involved. The faculty, participators and non-participators, rated issues that could be considered intrinsic factors as motivating for participation in ALN/DE, while administrators indicated a perception that faculty would be more motivated by factors that could be considered extrinsic. Similar to Dillon and Walsh [22], intrinsic factors were defined for the purpose of this study as ones that come from within the individual or benefit the program and students (e.g., "improve teaching," "greater flexibility for the students"). Extrinsic factors were defined for this study as ones relating to university administration support and encouragement to faculty to participate or that benefits only individual faculty member (e.g., "monetary support for participation" and "credit toward promotion and tenure"). These two categories of factors were supported through a factor analysis of all 46 motivating and inhibiting factor responses. Clearly, the administrators and faculty were not in agreement on what would motivate faculty to participate in ALN/DE programs.

The top inhibiting factors were rated very similarly across groups and all five top inhibiting factors appear to be more extrinsic in nature than intrinsic. Determining what factors would deter faculty from participating in ALN/DE appears easier than what would motivate.

The results of this study suggest that faculty are more likely to participate in ALN/DE programs due to interest in using computers in teaching, interest in exploring new opportunities for programs and students and interest in the intellectual challenge, rather than monetary or personal rewards. The inhibiting factors identified relate to issues essential for a program to be successful, i.e., institutional support for faculty, technical infrastructure and course development needs, supporting reports by Olcott and Wright [19] and Wolcott [20]. Teaching at a distance is not the same as teaching in the traditional classroom setting. New skills are required for the new environment. Attending to these concerns helps to minimize the inhibiting factors, but does not address motivating factors. While not all the inhibiting factors can be eliminated, recognition of these issues by all parties involved (e.g., faculty, administrators and students) may help in gaining 
support and participation by faculty in developing and teaching ALN/DE course offerings. And while not all faculty members will ever participate in DE for many reasons, understanding what does motivate participators may provide much needed information to administrators for developing incentives and minimizing barriers.

This study supports the work reported by Dillon [21] and Dillon and Walsh [22] and adds to the literature defining and understanding ALN/DE faculty. DE has evolved since the World Wide Web emerged. With digitally based ALN/DE, faculty must be technically adept to be successful teaching a distance course; therefore, faculty participation will depend on faculty comfort in general and in teaching with computer technology. For faculty already comfortable, teaching at a distance is a challenge to their technical and intellectual skills, and an opportunity to reach out to new audiences. For faculty not comfortable with computers, teaching at a distance is more than a challenge. Administrators must recognize these differences and provide the necessary opportunities to develop online pedagogical skills, which will only happen when faculty are comfortable using technology in their teaching. Teaching at a distance is not for every faculty member, but should not be limited to those comfortable with computers. Trust and understanding by both sides, administrators and faculty, will help in alleviating the inhibiting factors. Providing the technical and individual support needed for successful ALN/DE will begin to capitalize on motivating factors.

\section{LIMITATIONS}

The author would like to note there are a couple of limitations to this study. First of all, the survey adapted from Dr. Kristen Betts' dissertation research does not have reliability and validity statistics. From a statistical perspective, this presents a problem in inferring the results of this study are reliable and valid. However, this is a descriptive study. It very well may be that every institution's response to this survey would be different based on institutional culture and past experience with innovation. Continued replication of this study will begin to provide enough data for reliability and validity evidence. The results of this study were similar to those of Dr. Betts. The top two motivating factors for participants in this study were in the top five motivating factors from her sample. One top five motivating factor for non-participants was in the top five from her sample, and two faculty motivating factors identified by administrators in this study were listed in the top five from her sample. These differences may merely reflect institutional differences.

The second limitation relates to the fact that faculty were asked to rate to what extent the factors listed had motivated/inhibited or would motivate/inhibit them to/from participation in DE. For a non-participant, responses may reflect an ideal situation (i.e., "I would be influenced if the motivating factor was offered") rather than institutional reality where the factor is not offered. Participant responses may have been influenced by institutional reality, rather than considering the factors in an ideal situation. For instance, if credit toward P\&T is not available, then it may not have been noted as a motivating factor, but the lack thereof might have been noted more likely as an inhibiting factor. Replication of this study will need to be mindful of this concern.

\section{REFERENCES}

1. Knowles, M., The Modern Practice of Adult Education, New York, Association Press, 1970.

2. Field, J., Characteristics of OU Students, Teaching at a Distance Supplement, No 1., Milton Keynes, Open University, 1982. 
3. Sewart, D., Keegan, D., and Holmberg, B., Distance Education: International Perspectives, New York, Croom Helm, 1983.

4. Hiltz, S.R., The Virtual Classroom, Norwood, NJ, Ablex, 1994.

5. Keegan, D., The Foundations of Distance Education, Dover, NH, Croom Helm, 1986.

6. McIntosh, N.E., Woodley, A., and Morrison, V., Student Demand and Progress at the Open University: The First Eight Years, Distance Education, 1(1), 37-60, 1980.

7. Blumenstyk, G., A Feminist Scholar Questions How Women Fare in Distance Education, The Chronicle of Higher Education, 44(10), A36, 1997.

8. Canada, K., and Brusca, F., The Technological Gender Gap: Evidence and Recommendation for Educators and Computer-Based Instruction Designers, Educational Technology, Research and Development, 39(2), 43-51, 1991.

9. Faith, K., (Ed), Toward New Horizons for Women in Distance Education: International Perspectives, New York, Routledge, 1988.

10. Gose, B., Morehouse's Trinidad Connection Provides a Steady Stream of Top Black Students, The Chronicle of Higher Education, 44(17), A41-42, 1997.

11. DeVillar, R.A. and Fallis, C.J., Computers and Cultural Diversity: Restructuring for School Success, Albany, NY, Sunny Press, 1991.

12. Sanchez, I., and Gunawardena, C.N., Understanding and Supporting the Culturally Diverse Distance Learner. In Gibson, C.C. (Ed). Distance Learners in Higher Education, Madison, WI, Atwood, 1998.

13. Berge, Z.L., and Collins, M.P., Computer Mediated Communication and the Online Classroom, Volumes I, II and III, Cresskill, NJ, Hampton Press, 1995.

14. Forsyth, I., Teaching and Learning Materials and the Internet, London, Kogan Page Ltd, 1996.

15. Melton, R., Objectives, Competencies and Learning Outcomes: Developing Instructional Materials in Open and Distance Learning, Stirling, VA, Kogan Page Ltd, 1997.

16. Khan, B.J., (Ed), Web-Based Instruction, Englewood Cliffs, NJ, Educational Technology Publications, 1998.

17. Taylor, J.C., and White, J.V., Faculty Attitudes Towards Teaching in the Distance Education Mode: An Exploratory Investigation, Research in Distance Education, July, 7-11, 1991.

18. Clark, T., Attitudes of Higher Education Faculty Toward Distance Education: A National Survey, The American Journal of Distance Education, 7 (2), 19-33, 1993.

19. Olcott, D. and Wright, S.J. An Institutional Support Framework for Increasing Faculty Participation in Postsecondary Distance Education, The American Journal of Distance Education, 9 (3): 5-17, 1995.

20. Wolcott, L.L., Tenure, Promotion and Distance Education: Examining the Culture of Faculty Rewards, The American Journal of Distance Education, 11(2), 3-18, 1997.

21. Dillon, C., Faculty Rewards and Instructional Telecommunications: A View from the Telecourse Faculty, The American Journal of Distance Education, 3(2), 35-43, 1989.

22. Dillon, C.L. and Walsh, S.M., Faculty: The Neglected Resource in Distance Education, The American Journal of Distance Education, 6(3), 5-21, 1992.

23. Beaudoin, M.R., The Instructor's Changing Role in Distance Education, The American Journal of Distance Education, 4(2), 21-29, 1990.

24. Beaudoin, M.R., A New Professoriate for the New Millennium, DEOSNEWS, 8(5), 1998. Doc. N. 9800004. http://www.outreach.psu.edu/ACSDE/DEOS.html

25. Berge, Z.L., Changing Roles of Teachers and Learners are Transforming the Online Classroom, Online-Ed, August 30, 1998, Doc. No. 74. http://www.edfac.unimelb.edu.au/online-ed

26. Strain, J., The Role of the Faculty Member in Distance Education, The American Journal of Distance Education, 1(2), 61-65, 1987.

27. Hackman M.Z. and Walker, K.B., Instructional Communication in the Televised Classroom: The Effects of System Design and Teacher Immediacy on Students Learning and Satisfaction, Communication Education, 39(3), 196-209, 1990.

28. Merkley, D.J., Bozik, M., and Oakland, K. Investigating Support for Teachers Using Distance Learning in Education: A Case Study, DEOSNEWS, 7(11), 1997. Doc. No. 97-00011. http://www.outreach.psu.edu/ACSDE/DEOS.html

29. Betts, K.S., Personal communication, November 20, 1998.

30. Betts, K.S., Factors Influencing Faculty Participation in Distance Education in Postsecondary Education in the United States: An Institutional Study, Ph.D. dissertation, The George Washington University, 1998. 